FITRAH Jurnal Kajian Ilmu-ilmu Keislaman

Vol. 03 No. 2 Desember 2017

e-ISSN : 2460-2345, p-ISSN: 2442-6997

Web: jurnal.iain-padangsidimpuan.ac.id/index.php/F

\title{
PANDANGAN MAHASISWA PROGRAM STUDI PENDIDIKAN AGAMA \\ ISLAM TERHADAP ETIKA DOSEN DALAM PELAYANAN AKADEMIK \\ PADA FAKULTAS TARBIYAH DAN ILMU KEGURUAN IAIN PALANGKA RAYA
}

\author{
ABDULLAH \\ Institut Agama Islam Negeri Palangka Raya \\ Email : abdullah@iain-palangkaraya.ac.id
}

\begin{abstract}
This research aims to know the positive and negative view of the students of Islamic Education Study Program (PAI) on the lecturers' ethics in giving academic services at the Faculty of Education and Teacher Training of IAIN Palangka Raya, which include the lecturers' ethics in giving the courses, guiding the Teaching Practice (Praktek Mengajar), and guiding students in doing their proposal and thesis. This research is based on the qualitative descriptive method. The subject is the PAI students of 2013 of the Faculty of Education and Teacher Training-IAIN Palangka Raya. Technically, the data are collected through interview and documentation. It is then analyzed through data reduction, data presentation, and conclusion. The techniques of examining the validity of data is with triangulation of the source and peer examination through discussion. The result of the research shows that: First, in developing the lecture: (1) Positive view tells about exemplary, polite attitude, friendly, discipline, giving advices, and having noble character, (2) Negative one about undisciplined attitude, and lack of awareness and of appreciation of ethical values; Second, in guiding the teaching practice: (1) Positive outlook includes friendly, good guiding, experienced, and competent. (2) Negative one says about lack of attention to the students in the guiding process during preparation or during the practice of teaching; Third, in guiding the proposal and thesis: (1) Positive outlook says about giving advices and suggestions, thorough in correcting student writing, serious in giving guidance and spending time efficiently (2) Negative outlook says about unfriendly when providing consultation, not keeping the appointment, not giving the confirmation if there is cancellation of appointment, and seeming not to care about the student's need related to the proposal and thesis guidance.
\end{abstract}

Keywords: ethics, lecturer's ethics, and student's view

\section{Abstrak}

Penelitian ini bertujuan mengetahui pandangan positif dan negatif mahasiswa program studi Pendidikan Agama Islam (PAI) terhadap 
FITRAH Jurnal Kajian Ilmu-ilmu Keislaman

Vol. 03 No. 2 Desember 2017

etika dosen dalam pelayanan akademik pada Fakultas Tarbiyah dan Ilmu Keguruan IAIN Palangka Raya, yang meliputi etika dosen dalam membina perkuliahan, membimbing Praktik Mengajar (PM), dan membimbing proposal dan skripsi mahasiswa. Peneltian ini merupakan penelitian deskriptif kualitatif. Subjek penelitian ini adalah mahasiswa Program Studi PAI angkatan 2013 FTIK IAIN Palangka Raya. Teknik pengumpulan data yang digunakan adalah wawancara dan dokumentasi. Data dianalisis melalui reduksi data, penyajian data, dan penarikan kesimpulan. Teknik pemeriksaan keabsahan data menggunakan trianggulasi sumber dan pemeriksaan teman sejawat melalui diskusi. Hasil penelitian menunjukkan bahwa: Pertama, dalam membina perkuliahan: (1) Pandangan positif, yaitu keteladanan, sikap sopan santun, ramah, disiplin, memberi nasehat,dan berakhlak mulia, (2) Pandangan negatif yang tercermin dari sikap ketidakdisiplinan, subjektif dalam memberikan penilaian, dan lemahnya kesadaran dan penghayatan terhadap nilai etika; Kedua, dalam membimbing praktik mengajar: (1) Pandangan positif yang meliputi sikap ramah, membimbing dengan baik, berpengalaman, dan berkompeten. (2) Pandangan negatif yang ditunjukkan dengan kurangnya perhatian dalam proses bimbingan terhadap mahasiswa baik saat persiapan maupun selama praktek mengajar berlangsung; Ketiga, dalam membimbing proposal dan skripsi: (1) Pandangan positif: memberikan saran dan masukan, memberi nasehat, teliti dalam mengoreksi tulisan mahasiswa, memberi bimbingan dengan sungguh-sungguh dan tidak terlalu banyak memakan waktu (2) Pandangan negatif : tidak ramah saat mahasiswa berkonsultasi, tidak menepati janji, tidak mengkonfirmasi jika ada pembatalan janji, dan terkesan tidak memperdulikan terhadap keperluan mahasiswa terkait dengan bimbingan proposal dan skripsi.

Kata Kunci: Etika, Etika dosen, dan Pandangan Mahasiswa

\section{PENDAHULUAN}

Pendidikan semakin menuntut peran seorang dosen yang berkualitas. Untuk dapat menghasilkan dosen yang berkualitas, seperti yang diamanatkan oleh Undang-undang Republik Indonesia nomor 14 tahun 2005 tentang guru dan dosen Pasal 5 menyatakan; "Kedudukan dosen sebagai tenaga profesional berfungsi untuk meningkatkan martabat dan peran dosen sebagai agen pembelajaran, pengembang ilmu pengetahuan, teknologi, dan seni, serta pengabdi kepada masyarakat berfungsi untuk meningkatkan mutu pendidikan 
nasional". ${ }^{1}$

Secara umum dosen harus memiliki kompetensi pedagogik, kompetensi kepribadian, kompetensi sosial, dan kompetensi profesional. Kompetensi pedagogik berkaitan dengan kemampuan mengelola pembelajaran peserta didik. Kompetensi keperibadian berhubungan erat dengan kemampuan kepribadian yang mantap, berakhlak mulia, arif, dan berwibawa serta menjadi teladan peserta didik. Adapun kompetensi sosial merupakan kemampuan pendidik untuk berkomunikasi dan berinteraksi secara efektif dan efisien dengan peserta didik, sesama pendidik, orangtua/wali peserta didik, dan masyarakat sekitar. Kompetensi profesional adalah kemampuan penguasan materi pelajaran secara luas dan mendalam. ${ }^{2}$

Bagi mahasiswa, dosen yang sudah mengampu perkuliahan selama setahun lebih, mahasiswa tentu sudah tidak asing dengan sifat dan kebiasaan dosen. Dari sifat dan kebiasaan itulah yang menjadikan mahasiswa mempunyai dosen idola sehingga membuat mahasiswa selalu senang mengikuti mata kuliahnya maupun pelayanan akademik lainnya.

Berdasarkan penjajakan awal, terutama selama peneliti melayani mahasiswa pada Fakultas Tarbiyah dan Ilmu Keguruan (FTIK) IAIN Palangka Raya terdapat beberapa pandangan mahasiswa tentang etika dosen dalam pelayanan akademik, baik di dalam maupun di luar proses perkuliahan maupun pelayanan akademik lainnya. Sebagian mahasiswa berpandangan positif terhadap sikap dosen, mereka memilih perkuliahan yang diampu, dibimbing, dan diuji oleh dosen tertentu. Demikian juga sebaliknya, terdapat keluhan sebagian mahasiswa terkait pelayanan akademik dosen, seperti bimbingan/konsultasi yang kurang memuaskan. Dari pandangan tersebut, dapat ditarik garis besarnya mahasiswa memiliki pandangan positif dan negatif terhada petika dosen dalam pelayanan akademik. Oleh karena ini peneliti merasa tertarik untuk menguraikan hal tesrebut melalui penelitian ini.

\section{METODE PENELITIAN}

Jenis penelitian yang dilakukan adalah penelitian kualitatif. Penelitian kualitatif yaitu penelitian yang menjawab permasalahan yang memerlukan

\footnotetext{
${ }^{1}$ NOMOR 14 TAHUN 2005 Undang-undang Republik Indonesia, TENTANG GURU DAN DOSEN, n.d.

${ }^{2}$ Undang-undang Republik Indonesia.
} 
FITRAH Jurnal Kajian Ilmu-ilmu Keislaman

Vol. 03 No. 2 Desember 2017

pemahaman secara mendalam dalam konteks waktu dan situasi yang bersangkutan. Penelitian ini dilakukan secara wajar dan alami sesuai dengan kondisi fakta di lapangan dan tanpa adanya manipulasi. ${ }^{3}$

Subyek pada penelitian ini ialah mahasiswa pada Program Studi Pendidikan Agama Islam FTIK IAIN Palangka Raya. Adapun sumber data yang dimintai keterangannya dalam pengambilan data di lapangan adalah mahasiswa PAI angkatan 2013 FTIK IAIN Palangka Raya. Obyek dalam penelitian ini adalah pandangan mahasiswa terhadap etika dosen dalam pelayanan akademik yang meliputi pembina mata kuliah, penasehat akademik dan pembimbing proposal/skripsi. Dalam pengumpulan data peneliti menggunakan teknik wawancara dan dokumentasi, kemudian data dianalisis melalui reduksi data, penyajian data, dan penarikan kesimpulan. Sedangkan teknik pemeriksaan keabsahan data menggunakan triangulasi suber dan pemeriksaan teman sejawat melalui diskusi.

\section{DESKRIPSI TEORITIS}

\section{Pengertian Etika}

Etika berasal dari bahasa Yunani ethos (kata tunggal) yang berarti: tempat tinggal, padang rumput, kandang, kebiasaan, adat, watak, sikap, cara berpikir. Bentuk jamaknya adalah $t a$, etha, yang berarti adat istiadat. Dalam hal ini, kata etika sama pengertianya dengan moral. Moral berasal dari kata latin: mos(bentuk tunggal), atau mores (bentuk jamak) yang berarti adat istiadat, kebiasaan, kelakuan, watak, tabiat, akhlak, cara hidup. ${ }^{4}$

Etika dalam bahasa arab disebut akhlak, merupakan jamak dari kata khuluq yang berarti adat kebiasaan, perangai, tabiat, watak, adab, dan agama. ${ }^{5}$ Dalam kamus besar Bahasa Indonesia (KBBI) disebutkan bahwa etika diartikan sebagai ilmu tentang apa yang baik dan apa yang buruk dan tentang hak dan kewajiban moral (akhlak). ${ }^{6}$ Akhlak itu sendiri berasal dari kata al-khuluq (kebiasaan, perangai, tabiat dan agama),tingkah laku yang ada atau lahir dari

${ }^{3}$ Zainal Arifin, Penelitian Pendidikan Metode dan Paradigma Baru (Bandung: PT. Remaja Rosdakarya, 2011), hlm. 29.

${ }^{4}$ Abuddin Nata, Akhlak Tasawuf dan Karakter Mulia (Jakarta: Raja Grafindo, 2012), hlm. 75.

${ }^{5}$ Muhammad Alfan, Filsafat Etika Islam (Bandung: CV Pustaka Setia, 2011), hlm. 75.

${ }^{6}$ Depdikbud, Kamus Besar Bahasa Indonesia (Jakarta: Balai Pustaka, 2002), hlm. 309. 
manusia dengan sengaja, tidak dibuat-buat, dan sudah menjadi kebiasaan. Etika adalah tata cara sopan santun dalam masyarakat guna memelihara hubungan baik antar sesama. ${ }^{7}$

Dari uraian di atas dapat dipahami bahwa akhlak berbeda dengan etika. Kalau akhlak lebih bersifat transendental karena berasal dan bersumber dari Allah, maka etika bersifat relatif, dinamis, dan nisbi karena merupakan pemahaman dan pemaknaan manusia melalui ijtihadnya. Etika sebenarnya dapat dipahami sebagai sistem penilaian perilaku serta keyakinan untuk menentukan perbuatan yang pantas guna menjamin adanya perlindungan hakhak individu, mencakup cara-cara dalam mengambil keputusan untuk membantu membedakan hal-hal yang baik dan yang buruk serta mengarahkan apa yang seharusnya sesuai nilai-nilai yang dianut. Etika sebenarnya terkait dengan ajaran-ajaran moral yakni standar tentang benar dan salah yang dipelajari melalui proses hidup bermasyarakat. ${ }^{8}$

\section{Pelayanan Akademik Dosen}

Istilah pelayanan dalam Bahasa Indonesia berarti perbuatan melayani. Melayani diartikan sebagai aktivitas menolong; menyediakan segala sesuatu yang diperlukan orang lain; meladeni. ${ }^{9}$ Oleh karena itu, secara sederhana pelayanan berarti perbuatan menolong atau membantu orang lain sesuai yang dibutuhkannya. Apabila kebutuhan terpenuhi maka akan timbul rasa puas dari orang yang dilayani. Kepuasan ini terkait dengan kualitas pelayanan yang diterima oleh konsumen dari orang lain yang melayani. Pelayanan merupakan segala upaya guna mempertinggi kepuasan konsumen. ${ }^{10} \mathrm{Jadi}$, pelayanan adalah suatu kegiatan yang terjadi atas interaksi langsung antara seseorang dengan orang lain atau benda secara fisik dan menghasilkan kepuasan pelanggan.

Sebuah perguruan tinggi akan menarik dan membentuk citra yang baik terhadap publik perlu adanya dosen bermutu dan mutu akademik yang dapat dibanggakan serta memiliki kompetensi.

${ }^{7}$ Asmaran As, Pengantar Studi Akhlak, Cet-3 (Jakarta: PT. Raja Grafindo, 2002), hlm. 7.

8 Modul Pendidikan dan Pelatihan Prajabatan Golongan III, Etika Publik,(Jakarta : Lembaga Administrasi Negara Republik Indonesia, 2015), hlm.8-9

9 Wilfridus J.S. Poerwadarminta, Kamus Besar Bahasa Indonesia, Edisi Ketiga (Jakarta: Balai Pustaka, 2007), hlm. 674.

${ }^{10}$ Sri Hartini Jatmikowati, Manajemen Pelayanan Publik Menuju Good Governance (Malang: UM Press, 2013), hlm. 34. 
FITRAH Jurnal Kajian Ilmu-ilmu Keislaman

Vol. 03 No. 2 Desember 2017

1. Dosen Bermutu/Berkualitas, menurut pandangan Alma, dosen yang bermutu harus mempunyai kriteria berupa kompetensi keilmuan, penguasaan metode mengajar, pengendalian emosi, dan disiplin. ${ }^{11}$

2. Mutu Akademik

Secara konseptual mutu akademik adalah muara dari mutu proses pedidikan, alat, kurikulum dan fasilitas, yang tercermin pada mutu mengajar dosen, mutu bahan pelajaran dan mutu hasil belajar, akhirnya membentuk seperangkat kemampuan. ${ }^{12}$

Berhasil atau tidaknya penyelenggaraan pendidikan bermutu tergantung pada jumlah atau mutu para aktor atau petugas yang melaksanakannya. ${ }^{13}$ Dosen memiliki fungsi dominan dalam pelayanan akademik karena tugas dosen di sini adalah mengajar, membimbing, dan menguji. Adapun bentuk pelayanan pendidikan yang bermutu oleh seorang dosen adalah sebagai berikut:

a. Terjadinya kontak intensif antara pelayan dengan pengguna jasa. Artinya dosen dan mahasiswa dalam proses belajar mengajar selalu bertatap muka dan yang dimaksud kontak secara intensif dalam hal ini adalah dosen sering menyediakan waktu kepada mahasiswa untuk memberikan kesempatan bagi mahasiswa berkonsultasi mengenai hal yang berhubungan dengan matakuliah yang sedang diampu oleh dosen bersangkutan.

b. Pelayanan dilakukan secara tepat waktu dan tepat sasaran. Yakni kehadiran dosen pada saat memberi kuliah selalu tidak pernah telat dan selalu menghadiri perkuliahan, sementara yang dimaksud tepat sasaran adalah dosen memberikan materi sesuai dengan kebutuhan mahasiswa dan sesuai dengan perkembangan ilmu pengetahuan yang sedang berkembang pada saat itu.

c. Perbuatan melayani dilakukan secara hati-hati dan komprehensif. Artinya dosen disini diharapkan dapat menguasai materi perkuliahan yang diajarkan, sehingga pertanyaan-pertanyaan yang muncul dari mahasiswa ketika mahasiswa sedang kebingungan, dosen mampu menjelaskan dengan jelas dan mudah dimengerti.

${ }^{11}$ Buchari Alma dan Ratih Hurriyati, Manajemen corporate \& strategi pemasaran jasa pendidikan (Bandung: Alfabeta, 2008), hlm. 22.

${ }_{12}$ Alma dan Hurriyati, hlm. 24.

13 Mastuhu, Menata ulang pemikiran sistem pendidikan nasional dalam abad 21 (Yogyakarta: Safiria Insania Press, 2004), hlm. 109. 
d. Transparan menghadapi masalah-masalah yang tidak dapat diraba (intangible $)^{14}$.

\section{Kompetensi Dosen}

Dalam kaitannya dengan tugas dosen sebagai pendidik profesional dan ilmuwan dengan tugas utama untuk mentransformasikan, mengembangkan, dan menyebarluaskan ilmu pengetahuan, teknologi, dan seni melalui pendidikan dan pengajaran, penelitian, dan pengabdian kepada masyarakat, penting pula dicermati kompetensi-kompetensi yang harus dimiliki oleh dosen dalam menjalankan tugas dan kewajibannya dalam bidang pendidikan dan pengajaran, penelitian, dan pengabdian pada masyarakat (Tri Dharma Perguruan Tinggi).

Menurut Undang-Undang Republik Indonesia Nomor 14 Tahun 2005 Tentang Guru dan Dosen menyatakan bahwa kompetensi adalah seperangkat pengetahuan, keterampilan, dan perilaku yang harus dimiliki, dihayati, dan dikuasai oleh guru atau dosen dalam melaksanakan tugas keprofesionalan. Kompetensi-kompetensi yang harus dikuasai dan dihayati oleh dosen meliputi kompetensi pedagogik, kompetensi kepribadian, kompetensi sosial, dan kompetensi profesional. Kompetensi pedagogik berkaitan dengan kemampuan mengelola pembelajaran peserta didik. Kompetensi keperibadian berhubungan erat dengan kemampuan kepribadian yang mantap, berakhlak mulia, arif, dan berwibawa serta menjadi teladan peserta didik.Adapun kompetensi sosial merupakan kemampuan pendidik untuk berkomunikasi dan berinteraksi secara efektif dan efisien dengan peserta didik, sesama pendidik, orangtua/wali peserta didik, dan masyarakat sekitar.Kompetensi profesional adalah kemampuan penguasan materi pelajaran secara luas dan mendalam. ${ }^{15}$

\section{HASIL PENELITIAN DAN PEMBAHASAN}

\section{Hasil Penelitian}

\section{Etika Dosen Membina Perkuliahan}

a. Pandangan Positif Mahasiswa dalam Membina Perkuliahan

1) Memberi Teladan

Keteladanan merupakan salah satu wujud nyata dari perilaku positif yang dimiliki oleh seseorang terlebih bagi seorang dosen yang

\footnotetext{
${ }^{14}$ Sugi Rahayu, "Ekspektasi Mahasiswa Terhadap Pelayanan Akademik Fakultas Ilmu Sosial dan Ekonomi Universitas Negeri Yogyakarta," Jurnal Socia IV, no. 01 (n.d.).

${ }^{15}$ Undang-undang Republik Indonesia, Tentang Guru Dan Dosen.
} 
FITRAH Jurnal Kajian Ilmu-ilmu Keislaman

Vol. 03 No. 2 Desember 2017

tugasnya membimbing dan membina mahasiswa baik pada saat proses pembelajaran di dalam kelas maupun bimbingan di luar kelas, karena pada dasarnya perilaku baik yang ditunjukan oleh dosen menjadi contoh yang baik bagi mahasiswa. Sebagaimana yang diungkapkan oleh mahasiswa C:

“Dosen memberikan contoh teladan yang baik kepada mahasiswa, seperti berpakaian yang rapi dan sopan. Dan untuk menanamkan nilai-nilai keagamaan kepada mahasiswa, dosen senantiasa mengajak mahasiswa untuk berzikir bersama-sama ditengahtengah perkuliahan". ${ }^{16}$

Hal senada diungkapkan oleh mahasiswa A yang menyatakan bahwa:

“Dalam proses perkuliahan pada umumnya semua dosen mempunyai akhlak/etika terpuji, contohnya dalam memberikan penjelasan tentang materi perkuliahan, memberikan contoh dalam proses Kegiatan Belajar Mengajar(KBM) dengan menggunakan contoh perilaku yang baik, melalui KBM dosen juga memberikan perilaku disiplin, memberikan motivasi untuk semangat dalam mengikuti perkuliahan, memberikan nasehat kepada mahasiswa untuk meningkatkan kualitas ibadah, mengamalkan apa yang sudah diajarkan dalam perkuliahan kepada lingkungan masyarakat"17

Ungkapan lain yang dinyatakan oleh mahasiswa F:

"Sikap yang paling berkesan adalah ketika para dosen menunjukkan sikap profesional dalam menyampaikan materi serta kebiasaan khas dari masing-masing dosen. Saya sangat setuju dengan dosen yang sangat mengedepankan kedisiplinan serta sanksi bagi terlambat tanpa alasan yang akurat" ${ }^{18}$

Hal tersebut diperkuat oleh ungkapan mahasiswa E :

"Pada umumnya, sebenarnya para dosen itu baik/berperilaku terpuji, mereka tidak hanya mentransfer ilmu tetapi juga mencontohkan hal yang baik dari perilaku beliau, seperti disiplin waktu, tidak boleh terlambat mengerjakan tugas mandiri/kelompok, saya rasa itu semua bertujuan agar mahasiswa dilatih cakap berfikir dan menyelesiakan tugas dengan tepat waktu. Selain itu banyak dosen yang memberikan semangat, motivasi kepada para mahasiswanya, dengan tidak menjatuhkan semangatnya" ${ }^{19}$

16Wawancara tanggal 14 Juni 2017

17Wawancara tanggal 12 Juni 2017.

${ }^{18}$ Wawancara tanggal 16 Juni 2017.

${ }^{19}$ Wawancara tanggal 16 Juni 2017. 
Berdasarkan hasil wawancara di atas tergambar bahwa dosen tidak hanya menyampaikan pengetahuan (transfer of knowledge) secara umum akan tetapi dosen juga memberi arahan dan bimbingan kepada mahasiswa tentang pentingnya berperilaku baik dengan cara memberikan nasehat, dan yang terpenting adalah dosen mampu memberikan teladan yang baik kepada mahasiswa yang tujuannya agar mahasiswa mampu meneladaninya. Wujud nyata keteladanan itu diantaranya sikap sopan santun, ramah, disiplin, memberi nasehat yang ditunjukan oleh dosen pada saat berinteraksi dengan mahasiswa.

2) Beretika/berakhlak mulia

Dosen merupakan panutan bagi mahasisw, hal tersebut dapat dilihat dari sikap dosen yang mampu membina mahasiswa dengan baik. Sebagaimana yang diungkapkan oleh mahasiswa B bahwa:

"Dalam hal membina proses perkuliahan kebanyakan dosen membina dengan baik, yaitu mahasiswa dibimbing dan dijelaskan sampai benar-benar mengerti. Dan beruntungnya juga diselingi dengan dakwah yang membangun untuk diterapkan mahasiswa dikehidupan sehari-hari. Dalam paparan materinya juga diterangkan oleh dosen tersebut dengan tutur kata yang sopan dan beretika. Sehingga dapat ditiru oleh mahasiswa yang akan menjadi calon guru nantinya" ${ }^{\prime 20}$

Pernyataan yang sama juga diungkapkan oleh mahasiswa C:

"Selama dosen mengajar pada proses perkuliahan, dosen senantiasa menggunakan kata-kata yang lemah lembut, tegas dan lugas untuk mendidik mahasiswa, sehingga mahasiswa merasa senantiasa dibimbing menjadi mahasiswa yang lebih baik dan memiliki ilmu pengetahuan". ${ }^{21}$

Berdasarkan hasil wawancara menunjukan bahwa salah satu poin penting yang harus diperhatikan oleh dosen ketika proses pembelajaran maupun bimbingan adalah etika, baik itu terkait dengan sopan santun maupun sikap yang ditunjukan oleh dosen kepada mahasiswa.

${ }^{20}$ Wawancara tanggal 13 Juni 2017.

${ }^{21}$ Wawancara tanggal 14 Juni 2017. 
FITRAH Jurnal Kajian Ilmu-ilmu Keislaman

Vol. 03 No. 2 Desember 2017

b. Pandangan Negatif Mahasiswa dalam Membina Perkuliahan

1) Sikap ketidakdisiplinan

Sikap ketidakdisiplinan merupakan salah satu unsur yang menjadikan pandangan mahasiswa terhadap dosen menjadi negatif. Sebagaimana Mahasiswa B menyatakan:

"Dalam hal membina proses perkuliahan ada beberapa dosen yang kurang seperti halnya dalam kedisiplinan ada dosen yang sering terlambat masuk lamanya sampai 30 menit bahkan ada yang sampai 1 jam. Padahal dengan adanya dosen yang memiliki sikap tidak disiplin tersebut dapat menjadi contoh yang tidak baik bagi mahasiswa. ${ }^{22}$

Demikian juga diungkapkan oleh Mahasiswa A bahwa dosen tidak masuk mengajar dan membiarkan mahasiswa diskusi tanpa bimbingan. Seperti kutipan wawancara berikut ini :

"Dalam proses perkuliahan tidak jarang mahasiswa menemukan beberapa dosen yang memberikan materi perkuliahan tanpa bimbingan dosen, sehingga dalam kegiatan perkuliahan mahasiswa melakukan diskusi kurang efektif karena tidak ada bimbingan dari dosen." ${ }^{23}$

Secara garis besar dari hasil wawancara yang dilakukan, maka dapat diketahui bahwa ketidakdisiplinan yang ditunjukan oleh dosen menjadi salah satu indikator penilaian bagi mahasiswa terhadap perilaku negatif yang dimiliki dosen.

2) Subjektifitas dalam penilaian

Dosen dalam proses pembelajaran memiliki tugas utama yaitu merencanakan,melaksanakan dan mengevaluasi/memberikan penilaian. Dalam memberikan penilaian seorang dosen dituntut untuk bersikap objektif, akan tetapi terkadang sikap tersebut diabaikan oleh dosen sehingga mahasiswa merasa ada unsur ketidakadilan yang dilakukan oleh oleh dosen dan menjadikan pandangan mahasiswa terhadap dosen menjadi tidak baik. Sebagaimana yang diungkapkan oleh mahasiswa A bahwa:

“Dalam pemberian nilai ada beberapa dosen Fakultas Tarbiyah yang tidak mempertimbangkan (UAS,UTS, Tugas, Kehadiran), sehingga nilai yang diberikan oleh dosen membuat kebanyakan mahasiswa menjadi bingung dan mengecewakan. Dalam

22Wawancara tanggal 13 Juni 2017.

${ }^{23}$ Wawancara tanggal 12 Juni 2017. 
perkuliahan terdapan beberapa dosen yang mengeluarkan kata-kata yang membuat mahasiswa/i tersinggung" ${ }^{24}$

Selanjutnya pernyataan yang serupa diungkapkan oleh mahasiswa F:

"Tentang penilaian terhadap perkuliahan, meskipun tidak semua dosen sama, saya tidak setuju dengan sebagian dosen memberikan penilaian dengan subjektif. Sebagai contoh mahasiswa yang aktif, mengerjakan tugas, dan bisa mengerjakan UTS maupun UAS justru mendapatkan nilai yang lebih rendah dibandingkan mereka tidak aktif dan tidak jujur dalam mengerjakan UTS dan UAS" ${ }^{25}$

Berdasarkan hasil wawancara dapat disimpulkan bahwa penilain merupakan komponen penting dalam perkuliahan. Oleh sebab itu, objektifitas dalam memberikan penilaian oleh dosen kepada mahasiswa dapat menjadi sebuah keharusan. Akan tetapi pada kenyataannya masih ada sebagian dosen yang memberikan penilaian kepada mahasiswa tidak mengutamakan prinsip tersebut, sehingga mahasiswa yang benarbenar melaksanakan segala tugas yang diberikan oleh dosen terkadang mendapatkan nilai yang tidak sesuai dan sebaliknya mahasiswa yang hanya memenuhi sebagian dari tugas mendapatkan nilai yang lebih tinggi. Hal tersebut sangat berpengaruh terhadap pandangan mahasiswa terhadap dosen.

c. Tidak beretika/berakhlak

Etika sangat diperlukan baik bagi dosen maupun mahasiswa. Etika yang baik akan melahirkan perilaku yang baik. Akan tetapi etika yang tidak baik juga akan melahirkan tingkah laku yang tidak baik. Etika seorang dosen dalam proses pembelajaran maupun bimbingan menjadi sorotan bagi mahasiswa. Sebagaimana yang diungkapkan oleh mahasiswa D: "Dosen condong bukan sebagia fasilitator, sehingga ketika melakukan diskusi dosen cenderung mengabaikan atau tidak mempedulikan saat diskusi". ${ }^{26}$

Menurut Mahasiswa B:

"Dalam tutur bahasanya ada dosen yang terkesan kasar karena dipengaruhi oleh mood beliau yang sedang tidak bagus atau karena ada masalah pribadi sehingga dilampiaskan ke

\footnotetext{
24Wawancara tanggal 12 Juni 2017.

${ }^{25}$ Wawancara tanggal 16 Juni 2017.

26Wawancara tanggal 15 Juni 2017.
} 
FITRAH Jurnal Kajian Ilmu-ilmu Keislaman

Vol. 03 No. 2 Desember 2017

mahasiswa. Dan ada juga dosen yang terkesan cuek entah mahasiswa itu sudah paham dengan yang dijelaskan atau malah belum mengerti, dia hanya berfikir yang terpenting tugasnya dalam mengajar sudah dijalankan. Dalam berbicara menurut saya lebih baik menggunakan bahasa Indonesia, karena masih banyak dosen yang terkadang menggunakan bahasa daerah" ${ }^{27}$

Menurut Mahasiswa E:

"Yang menjadi hal negatif (dosen) ialah memberi harapan palsu(PHP) memberikan janji kalau masuk kuliah padahal tidak masuk, atau sudah ada janji bertemu dikampus, tetapi dosen tidak ada ditempat, selain itu saya rasa dosen juga tidak harus menganggap dirinya paling berharga, maksudnya hendaknya tidak berperilaku Judes, atau mengerikan/seram di hadapan mahasiswa, misalnya ada mahasiswa yang terlambat, dosen jangan memalukannya dengan cara memarahi di depan temantemannya, karena hal yang demikian sangat menusuk hati mahasiswa. Selain itu apabila menasehati mahasiswa jangan dengan suara yang keras, apalagi ditengah banyak orang, hal seperti itu sama saja memalukan mahasiswa dengan cara yang halus". ${ }^{28}$

Menurut Mahasiswa G :

"Terkadang sebagian dosen membutuhkan waktu yang sangat lama hanya untuk membalas SMS mahasiswa yang ingin berkonsultasi, bahkan saya rasa hal terparah ketika hanya ingin meminta tanda tangan saja begitu seharusnya". ${ }^{29}$

Berdasarkan hasil tiga ungkapan yang didapat melalui wawancara di atas dapat ditarik kesimpulan bahwa dosen dalam proses interaksi dengan mahasiswa harus menunjukan etika yang baik. Akan tetapi pada kenyataannya dosen tidak mampu menunjukan sifat dan sikap yang baik kepada mahasiswa pada saat proses pembelajaran maupun di luar proses pembelajaran. Hal tersebut terbukti dari sikap ketidaksantunan yang ditujukan oleh dosen.

\section{Etika Dosen dalam Membimbing Praktik Mengajar (PM)}

a. Pandangan Positif Mahasiswa Membimbing Praktik mengajar Berdasarkan wawancara, pandangan positif mahasiswa terhadap etika dosen dalam membimbing Praktik mengajar antara lain: Ramah,

\footnotetext{
27Wawancara tanggal 13 Juni 2017.

${ }^{28}$ Wawancara tanggal 16 Juni 2017.

${ }^{29}$ Wawancara tanggal 19 Juni 2017.
} 
Membimbing dengan baik(seperti membuat RPP, cara berkomunikasi dalam mengajar), dan berpengalaman dan kompeten.

Hal ini sejalan dengan apa yang telah diungkapkan mahasiwa A: “Dalam bimbingan praktek mengajar (PM) sebagian dosen sudah menjalankan tugasnya dengan benar yaitu membimbing penulisan RPP dan isi materi yang dicantumkan" ${ }^{30}$

Menurut Mahasiswa B:

“Dalam hal membimbing PM 1 saya rasa sudah cukup baik, karena dosen yang dipilih menjadi pembimbing PM memang yang sudah berpengalaman dan kompeten dalam bidangnya masing-masing". 31

Menurut Mahasiswa C :

"Kami diajarkan bagaimana cara membuat RPP yang baik dan benar, kami juga diajarkan cara berkumonikasi yang baik dalam proses belajar mengajar, selain itu kami juga diajarkan apa yang boleh dan apa yang tidak boleh dilakukan seorang guru kepada siswa ketika proses belajar mengajar berlangsung, sehingga kami memiliki banyak pengetahuan bagaimana cara menjadi seorang guru yang disukai dan disegani oleh peserta didik". ${ }^{32}$

Mahasiswa D mengungkapkan:

"Mengajarkan cara-cara mengajar dengan sunggung-sungguh, sehingga mahasiswa yang awalnya tidak memiliki keterampilan untuk mengajar akan memahaminya, lebih-lebih bisa mempraktikkan apa yang telah dicontohkan oleh dosen sehingga dalam penampian PM I dapat maksimal untuk kemudian masuk ke PM II" ${ }^{33}$

Menurut Mahasiswa G:

"sangat ramah dengan mahasiswa/i ketika membina pada saat PM I atau bimbingan judul dan proposal,memberikan ide-ide yang membuat pemikiran mahasiswa yang awalnya stag menjadi cerah dan semangat lagi untuk menggarap proposal, memiliki sikap ringan tangan untuk memberikan sarana agar mahasiswa cepat seminar proposal seperti meminjamkan buku dan menyumbangkan pemikiran yang berharga". ${ }^{34}$

Berdasarkan hasil wawancara diatas menunjukan bahwa dosen mampu melaksanakan salah satu tugannya yaitu memberikan bimbingan

\footnotetext{
${ }^{30}$ Wawancara tanggal 12 Juni 2017.

${ }^{31}$ Wawancara tanggal 13 Juni 2017.

32Wawancara tanggal 14 Juni 2017.

33Wawancara tanggal 15 Juni 2017.

34Wawancara tanggal 19 Juni 2017.
} 
FITRAH Jurnal Kajian Ilmu-ilmu Keislaman

Vol. 03 No. 2 Desember 2017

kepada mahasiswa. Sikap positif yang ditujukan oleh dosen mampu membawa mahasiswa ke arah yang lebih baik.

d. Pandangan Negatif Mahasiswa dalam Membimbing Praktik Mengajar(PM)

Berdasarkan wawancara, pandangan Negatif mahasiswa terhadap etika dosen dalam Membimbing Praktik Mengajar antara lain : tidak memberikan masukan RPP yang dibuat mahasiswa, terjadi perbedaan format RPP antar dosen, dan tidak memperhatikan mahasiswa tampil sampai tertidur, dan tidak menghadiri pelaksanaan PM. Hal ini sejalan dengan apa yang telah diungkapkan mahasiwa A:

"Dalam bimbingan Praktik mengajar ada beberapa dosen yang tidak memberikan masukan kepada mahasiswa dalam penulisan RPP. Dalam penulisan RPP sebagian dosen ada yang tidak konsisten antara pertama sampai bimbingan selanjutnya, dosen A mengatakan penulisan sudah benar dan tepat seperti yang dicontohkan, namun setelah pada bimbingan dosen yang lain hal yang sudah benar bisa jadi dirubah karena kurang tepat. $^{35}$

Menurut Mahasiswa C:

"Ketika bimbingan PM, dosen sudah melaksanakan bimbingan dengan baik, tapi ada sebagian dosen pada saat PM berlangsung, tidak terlalu memperhatikan mahasiswa yang tampil dan malah ketiduran diruangan, sehingga dosen tersebut tidak bisa mengoreksi mahasiswa yang tampil secara baikdan benar,karena tidak melihat apa kesalahan yang dilakukan mahasiswa yang tampil". ${ }^{36}$

Menurut Mahasiswa D: “Terkadang dosen ada yang tidak menghadiri saat PM I dilakukan. Setiap dosen memiliki pandangannya sendiri-sendiri, contohnya saat pembuatan RPP antara dosen 1 dan yang lainnya pasti berbeda sehingga mempersulit mahasiswa PM $1 .^{37}$

Berdasarkan hasil wawancara menunjukan bahwa dalam proses bimbingan Praktik Mengajar dosen tidak mampu menunjukan sikap yang semestinya dimiliki oleh seorang pembimbing karena dalam proses pembimbingan dosen tidak mampu mengarahkan mahasiswa dalam membuat RRP dan kurangnya sikap menghargai terhadap apa yang telah dikerjakan mahasiswa dan seringkali dosen mempersulit proses bimbingan

\footnotetext{
${ }^{35}$ Wawancara tanggal 12 Juni 2017.

36Wawancara tanggal 14 Juni 2017.

37Wawancara tanggal 15 Juni 2017.
} 
mahasiswa. Hal tersebut dapat mempengaruhi padangan mahasiswa kepada dosen yang awalanya positif menjadi negatif.

\section{Etika Dosen dalam Membimbing Proposal dan Skripsi}

a. Pandangan Positif Mahasiswa dalam Bimbingan Skripsi

Berdasarkan wawancara, pandangan positif mahasiswa terhadap etika dosen dalam Membimbing proposal/skripsi antara lain: dosen memberikan saran dan masukan yang baik, memberi nasehat, teliti dalam mengoreksi tulisan mahasiswa, memberi bimbingan dengan sungguhsungguh dan melakukan bimbingan tidak terlalu banyak memakan waktu. Hal ini sejalan dengan apa yang telah diungkapkan Mahasiswa A:

"Pada saat bimbingan proposal dosen menyikapi mahasiswa dengan baik, dalam bimbingan selanjutnya dosen memberikan saran dan masukan berupa teori yang relevan dengan judul proposal" Dan "menurut saya dalam hal pengajuan judul kebanyakan dosen pembimbing mengarahkan sudah cukup baik dan mahasiswa dapat memahaminya". ${ }^{38}$

Menurut Mahasiswa B:

"Selama bimbingan proposal skripsi menurut pengalaman saya, saya telah dibimbing dengan baik oleh dosen pembimbing saya, hal yang saya rasakan ketika mau konsultasi, dia selalu memberikan nasehat kepada saya agar menjadi yang lebih baik lagi, beliau sangat teliti mengoreksi hasil penulisan saya, sehingga saya benar-benar dibimbing untuk bisa menulis dengan tata cara penulisan yang baik dan benar, beliaupun selalu melayani mahasiswa dengan ramah ketika mahasiswa ingin konsultasi mengenai proposal skripsi" ${ }^{39}$

Menurut Mahasiswa C mengungkapkan: "Memberikan bimbingan secara sungguh-sungguh, sehingga ketika mahasiswa melakukan bimbingan tidak terlalu banyak memakan waktu atau kembali merevisi proposal/skripsi tersebut" ${ }^{40}$

Menurut Mahasiswa E memberikan pandangan sebagai berikut: "Setelah pembimbing ditetapkan, awalnya saya takut kalau dosen pembimbing saya sulit ditemui, judes, dan sebagainya. Tetapi ternyata, Allah mempunyai rencana yang lebih baik. Dosen pembimbing saya berperilaku lemah lembut dan sangat

\footnotetext{
${ }^{38}$ Wawancara tanggal 12 Juni 2017.

${ }^{39}$ Wawancara tanggal 13 Juni 2017.

40Wawancara tanggal 15 Juni 2017.
} 
FITRAH Jurnal Kajian Ilmu-ilmu Keislaman

Vol. 03 No. 2 Desember 2017

membimbing, agar penelitian saya terarah. Beliau juga tidak sekedar mencoret tetapi juga memberikan masukan/saran yang bagus.Hal ini patut dicontoh oleh dosen lainnya, bahwa menjadi dosen pembimbing tidak hanya bertugas untuk sekedar mencoret, tetapi juga membimbing dengan sebenarnya, mengarahkan dengan setulusnya" ${ }^{41}$

Menurut Mahasiswa G:

"sangat ramah dengan mahasiswa/i ketika bimbingan judul dan proposal,memberikan ide-ide yang membuat pemikiran mahasiswa yang awalnya stag menjadi cerah dan semangat lagi untuk menggarap proposal, memiliki sikap ringan tangan untuk memberikan sarana agar mahasiswa cepat seminarproposal seperti meminjamkan buku dan menyumbangkan pemikiran yang berharga". ${ }^{42}$

Berdasarkan hasil wawancara diatas menunjukan bahwa pandangan positif terhadap dosen pada saat bimbingan proposal/skripsi tergambar dari sikap dosen yang mampu mengarahkan mahasiswa dalam penulisan proposal/skripsi, selain itu sikap dosen yang ramah kepada mahasiswa dan memberikan ide-ide yang dapat membuka fikiran mahasiswa untuk melahirkan ide baru.

b. Pandangan Negatif Mahasiswa dalam pembimbingan Proposal/Skripsi

Berdasarkan wawancara, pandangan Negatif mahasiswa terhadap etika dosen dalam membimbing proposal/skripsi antara lain : dosen sulit ditemui/dicari meskipun telah menentukan waktu untuk berkonsultasi, ingkar janji, kurang maksimal dalam membimbing, tidak membalas wa/sms dan tidak mengangkat telpon mahasiswa yang ingin konsultasi.Hal ini sejalan dengan apa yang telah diungkapkan mahasiswa A:

"Pada saat bimbingan ada sebagian dosen yang memberikan coretan/masukkan kepada mahasiswa, namun mahasiswa tidak mengerti apa yang diinginkan. Ada beberapa dosen yang memberikan harapan palsu kepada mahasisa, mahasiswa sangat resah kepada dosen yang jarang ada dikampus waktu mahasiswa terbuang gara-gara menunggu dosen. Pada saat mengerjakan/mengoreksi proposal, dosen memerlukan satu minggu padahal yang dikoreksi cuma sedikit, seharusnya untuk

${ }^{41}$ Wawancara tanggal 16 Juni 2017.

42Wawancara tanggal 19 Juni 2017. 
mengoreksi proposal dalam satu minggu sudah bisa dari BAB I sampai dengan BAB III" ${ }^{\prime 3}$

Menurut Mahasiswa B:

"Ketika pengajuan judul ada beberapa dosen yang berbeda pendapat bahkan terkesan cuek dan tidak peduli dengan tingkat pemahaman mahasiswanya terhadap judul yang diajukan, seperti halnya penasehat akademik beliau hanya bisa mencoret dan merubah sedikit judul dari mahasiwanya tanpa membimbing mahasiswa tersebut dalam hal menyelesaikan latar belakang dan lain sebagainya. Pembimbing tersebut hanya langsung menandatangi surat persetujuan judulnya tanpa dikoreksi hasil yang dikerjakan mahasiswa. Terkadang ketika ingin konsultasi ada beberapa dosen yang sulit untuk ditemui ketika sudah berjanji untuk bertemu, dosen itu malah tidak datang-datang untuk menemuai mahasiswanya. Hal kecil ini kiranya perlu digaris bawahi oleh para dosen untuk lebih memahami kendala-kendala yang dialami mahasiswa dalam menyelesiakan S1", ${ }^{44}$

Menurut Mahasiswa C:

"Berdasarkan pengalaman saya, ada beberapa hal yang terkadang membuat mahasiswa menjadi tidak enak hati, yaitu ketika mahasiswa sms atau menelpon tidak pernah diangkat oleh dosen, jadi membuat mahasiswa tidak tahu kepastian kapan bisa bertemu dan berkonsultasi dengan dosen yang bersangkutan. Selain itu, menurut pengalaman saya yang membuat mahasiswa tidak enak hati, ketika bimbingan proposal skripsi belum selesai, dosen bersangkutan keluar kota selama berminggu-minggu, padahal mahasiswa sudah membuat janji sebelumnya kepada dosen yang bersangkutan" ${ }^{45}$

Menurut Mahasiswa E:

"Untuk dosen pembimbing yang lebih baik perlunya menyadari untuk membalas SMS dari mahasiswa yang ingin bertemu konsultasi, SMS saya tidak dibaca, hal ini kiranya perlu diperhatikan oleh dosen lain, bahwa balasan dari dosen pembimbing itu sangatlah diharapkan dan berarti bagi mahasiswanya" ${ }^{46}$

\footnotetext{
43Wawancara tanggal 12 Juni 2017.

44Wawancara tanggal 13 Juni 2017.

${ }^{45}$ Wawancara tanggal 14 Juni 2017.

46Wawancara tanggal 16 Juni 2017.
} 
FITRAH Jurnal Kajian Ilmu-ilmu Keislaman

Vol. 03 No. 2 Desember 2017

Berdasarakan hasil wawancara diatas menunjukan bahwa berbagai pandangan negatif terhadap dosen pada saat membimbing proposal/skripsi bagi mahasiswa diantaranya sikap dosen yang terkadang tidak ramah saat menghadapi mahasiswa yang ingin berkonsultasi tentang proposal/skripsinya, dosen juga tidak menepati janji kepada mahasiswa dan tidak mengkonfirmasi jika ada pembatalan janji dan dosen juga terkesan tidak memperdulikan terhadap keperluan mahasiswa terkait dengan bimbingan proposal/skripsi. Hal tersebut yang menyebabkan pandangan mahasiswa terhadap dosen menjadi negatif.

Dari penyajian data penelitian di atas dapat dipetakan dua pandangan mahasiswa Program Studi Pendidikan Agama Islam (PAI) terhadap etika dosen dalam pelayanan akademik yang meliputi pandangan dalam membina perkuliahan, membimbing Praktek Mengajar (PM), dan membimbing proposal/skripsi. Secara umum dua pandangan yang dimaksud adalah pandangan positif dan pandangan negatif dalam pelayanan akademik.

\section{Pembahasan}

Pandangan positif yang diberikan oleh mahasiswa terhadap etika dosen dalam pelayanan akademik menunjukkan suatu kesan pada profesionalisme dan kepribadian dosen baik berupa sikap maupun tindakannya. Pandangan positif ini pada dasarnya memiliki pengaruh yang positif-kontruktif bagi mahasiswa dalam kegiatan akademiknya seperti perkuliahan, praktek mengajar, dan penyusunan tugas akhir proposal/skripsi. Di sisi lain pandangan positif ini juga akan mempengaruhi karakter dan etika dalam diri mahasiswa itu sendiri. Pandangan positif mahasiswa terhadap etika dosen seperti keteladanan dalam sikap, tutur kata dan perilaku, kesopanan, disiplin, dan nasehat kebaikan, secara langsung maupun tidak langsung dapat berimplikasi pada sikap, perilaku, dan motivasi dalam menjalankan aktivitas akademiknya.

Pada aspek membina perkuliahan, kesan positif terbangun melalui interaksi antara dosen dan mahasiswa dalam perkuliahan. Dosen sebagai tenaga pendidik dan ilmuwan tidak hanya mempunyai tanggung jawab melakukan transfer ilmu pengetahuan, teknologi, dan seni pada mahasiswa, namun juga memiliki tanggung jawab moral dan etis untuk membimbing, membina, dan mengembangkan potensi spiritual, etika (akhlak), dan aspek sosial dalam diri mahasiswa. Tentu saja bimbingan dan pembinaan yang dilakukan oleh dosen terhadap mahasiswa bukan dalam bentuk indoktrinasi, tetapi lebih 
mengedepankan proses dialog dan komunikasi multi arah sehingga akan terbangun suatu kesadaran yang mampu membentuk sikap dan perilaku positif dalam diri mahasiswa.

Dosen yang disiplin dan tepat waktu serta kemampuan mengelola perkuliahan menunjukkan kapasitasnya sebagai tenaga pendidik yang memiliki kompetensi profesional, sementara keteladanan, sopan santun, dan etika yang baik menunjukkan kompetensi kepribadian. Kemudian kemampuan dalam mengelola pembelajaran, memotivasi, dan penguasaan materi merupakan cerminan dari kompetensi pedagogiknya.

Pada aspek pelayanan akademik pada Praktek Mengajar (PM) pandangan positif mahasiswa terhadap etika dosen nampak dalam perencanaan mengajar seperti bimbingan penyusunan RPP, penyiapan materi ajar, dan kemampuan mengajar. Mahasiswa menyadari bahwa bimbingan dosen pada Praktek Mengajar menjadi penting mengingat pengalaman, pengetahuan, dan kemampuan yang dimiliki dosen melebihi kemampuan mahasiswa. Pada konteks ini mahasiswa merasa bahwa kemampuan mengajarnya yang minim dan persoalan administrasi dalam pendidikan dan pengajaran dapat ditingkatkan, dan beban mental (tidak percaya diri, nervous) saat mengajar dapat diminimalisir.

Penyusunan proposal sebagai rencana penelitian dan skripsi yang menjadi tugas akhir mahasiswa membutuhkan suatu bimbingan yang intens dan berkesinambungan. Tanpa bimbingan yang memadai dari dosen akan sulit bagi mahasiswa yang bersangkutan dalam memilih topik dan menyusun rencana penelitian, dan menyelesaikan skripsi dengan baik.

Kesan positif mahasiswa terhadap dosen dalam bimbingan penyusunan proposal dan skripsi biasanya nampak pada keseriusan dan profesionalisme dosen dalam memberikan bimbingan. Dosen yang profesional dalam membimbing ditunjukkan melalui kemampuannya dalam memberikan bimbingan teknis-praktis seperti tata cara penulisan karya ilmiah, dan bimbingan yang lebih substansial seperti argumen dan logika dalam penulisan karya ilmiah dan penggunaan metodologi penelitian yang tepat. Selain itu dosen juga memberikan bimbingan moril dengan dukungan, nasehat, koreksi positif serta motivasi pada mahasiswa bimbingannya.

Selain pandangan dan kesan positif mahasiswa terhadap etika dosen dalam pelayanan akademik, ada pula pandangan negatif mahasiswa terhadap 
FITRAH Jurnal Kajian Ilmu-ilmu Keislaman

Vol. 03 No. 2 Desember 2017

dosen. Pandangan-pandangan negatif yang dimaksud meliputi aspek pembinaan perkuliahan, bimbingan Praktek Mengajar (PM), dan bimbingan dalam penyusunan proposal/skripsi. Pandangan negatif muncul melalui sikap dan perilaku yang ditampilkan oleh dosen pada mahasiswa dalam kegiatan pelayanan akademik.

Pandangan negatif di satu sisi menunjukkan kurangnya penghayatan dan kesadaran pada tanggung jawab, tugas, dan fungsinya sebagai tenaga pendidik, sementara di sisi yang lain sebagai cerminan lemahnya aspek etika yang ada dalam diri yang bersangkutan. Pengaruh maupun dampak negatif yang timbul dari pandangan negatif tersebut nampak pada aktivitas akademik mahasiswa maupun hubungan pribadi mahasiswa dengan dosennya. Mahasiswa yang memiliki pandangan negatif pada etika dosen akan mempengaruhi aktivitas akademiknya seperti menurunnya semangat dalam mengikuti perkuliahan dan semangat untuk mengkaji topik-topik dalam perkuliahan. Pada hubungan pribadi antara mahasiswa dan dosen menjadi renggang, ada perasaan traumatis dalam diri mahasiswa, dan lain sebagainya. Dampak negatif yang lebih nyata yang timbul dari pandangan negatif mahasiswa terhadap etika dosen adalah rendahnya atau terjadinya penurunan prestasi akademik yang dialami oleh mahasiswa.

Pandangan negatif dalam perkuliahan tergambar jelas pada ketidakdisiplinan dosen dalam menghadiri perkuliahan, seperti terlambat dan tidak hadir tanpa alasan. Kemudian kurang memberikan bimbingan pada mahasiswa dalam pembelajaran dan saat diskusi, dan kurangnya persiapan dalam mengajar. Ada pula pandangan negatif mahasiswa terhadap dosen seperti memberikan penilaian yang sifatnya subjektif tanpa mempertimbangkan objektivitas dan hasil karya serta tugas yang dibuat oleh mahasiswa. Pandanganpandangan negatif tersebut menunjukkan lemahnya kompetensi pedagogik dan profesional yang dimiliki dosen sebagai tenaga pendidik dan ilmuwan.

Berkaitan dengan lemahnya kompetensi kepribadian tergambar dalam aktivitas perkuliahan, dimana mahasiswa menjumpai dosennya memiliki sikap dan perilaku yang tidak layak dicontoh seperti kurang santun dalam bertutur kata, ada kesan kasar dalam berkata, dan kurang bijak dalam memberikan teguran kepada mahasiswa.

Pada aspek membimbing Prakter Mengajar juga tidak luput dari pandangan negatif mahasiswa terhadap dosen. Pandangan negatif tertuju pada 
kurangnya bimbingan dan arahan dosen terhadap format RPP yang dibuat mahasiswa.

Adapun pada aspek bimbingan penyusunan proposal dan skripsi, pandangan negatif juga muncul. Hal ini seperti ditunjukkan pada kurang lancar komunikasi yang terbangun antara mahasiswa dan dosen, begitu pun sebaliknya. Contohnya adalah kesulitan dalam menemui dosen pembimbing, pembatalan janji berkonsultasi, keluar kota karena kesibukan, dan lainnya. Selain itu pandangan negatif juga terjadi pada kurang intensifnya bimbingan konsultasi yang diberikan dosen pada mahasiswa bimbingannya.

Proses bimbingan dalam penyusunan proposal dan skripsi sejatinya membutuhkan keseriusan yang berlangsung secara berkesinambungan agar hasil yang diraih oleh mahasiswa berupa temuan penelitian bermanfaat secara teoritis maupun praktis. Tanpa bimbingan yang optimal mahasiswa bimbingan akan sulit menyusun dan menyelesaikan tugas akhirnya dengan baik sesuai waktu yang ditentukan.

Demikianlah berbagai pemaparan serta analisis pandangan mahasiswa terhadap etika dosen dalam pelayanan akademik yang meliputi membina perkuliahan, membimbing Prakter Mengajar (PM), dan membimbing penyusunan proposal dan skripsi. Pandangan mahasiswa muncul saat terjadi interaksi dan berlangungnya proses komunikasi antara mahasiswa dan dosen maupun sebaliknya, baik yang terjadi dalam konteks perkuliahan maupun di luar perkuliahan.

Pandangan mahasiswa terhadap etika dosen pada dasarnya beragam, namun secara umum dibagi menjadi 2 (dua) yaitu positif dan negatif. Pandangan positif lahir ketika mahasiswa mengalami dan merasakan sikap dan perilaku yang ditampilkan dosen berada dalam koridor yang sesuai dengan kode etik dosen, norma sopan santun, dan ajaran agama. Sementara itu pandangan negatif muncul tatkala sikap dan perilaku yang diwujudkan dosen bertentangan dengan kode etiknya, norma sopan santun, dan ajaran agama.

\section{PENUTUP}

Berdasarkan hasil penelitian di atas, diperoleh simpulan sebagai berikut:

1. Pandangan mahasiswa terhadap etika dosen dalam membina perkuliahan:(1) Pandangan positif yaitu keteladanan, sikap sopan santun, ramah, disiplin, memberi nasehat,dan berakhlak mulia, (2) Pandangan negatif yang tercermin 
FITRAH Jurnal Kajian Ilmu-ilmu Keislaman

Vol. 03 No. 2 Desember 2017

dari sikap ketidakdisiplinan, subjektif dalam memberikan penilaian, dan lemahnya kesadaran dan penghayatan terhadap nilai etika

2. Pandangan mahasiswa terhadap etika dosen dalam membimbing praktik mengajar: (1) Pandangan positif yang meliputi sikap ramah, membimbing dengan baik, berpengalaman, dan berkompeten. (2) Pandangan negatif yang ditunjukkan dengan kurangnya perhatian dalam proses bimbingan pada mahasiswa baik saat persiapan maupun pelaksanaan praktek mengajar.

3. Pandangan mahasiswa terhadap etika dosen dalam membimbing proposal dan skripsi: (1) Pandangan positif: memberikan saran dan masukan, memberi nasehat, teliti dalam mengoreksi tulisan mahasiswa, memberi bimbingan dengan sungguh-sungguh dan tidak terlalu banyak memakan waktu (2) Pandangan negatif : tidak ramah saat mahasiswa berkonsultasi, tidak menepati janji, tidak mengkonfirmasi jika ada pembatalan janji, dan terkesan tidak memperdulikan terhadap keperluan mahasiswa terkait dengan bimbingan proposal/skripsi. 


\section{DAFTAR PUSTAKA}

Alfan, Muhammad. Filsafat Etika Islam. Bandung: CV Pustaka Setia, 2011.

Alma, Buchari, dan Ratih Hurriyati. Manajemen corporate $\mathcal{E}$ strategi pemasaran jasa pendidikan. Bandung: Alfabeta, 2008.

Arifin, Zainal. Penelitian Pendidikan Metode dan Paradigma Baru. Bandung: PT. Remaja Rosdakarya, 2011.

Asmaran As. Pengantar Studi Akhlak. Cet-3. Jakarta: PT. Raja Grafindo, 2002.

Depdikbud. Kamus Besar Bahasa Indonesia. Jakarta: Balai Pustaka, 2002.

Jatmikowati, Sri Hartini. Manajemen Pelayanan Publik Menuju Good Governance. Malang: UM Press, 2013.

J.S. Poerwadarminta, Wilfridus. Kamus Besar Bahasa Indonesia, Edisi Ketiga. Jakarta: Balai Pustaka, 2007.

Mastuhu. Menata ulang pemikiran sistem pendidikan nasional dalam abad 21. Yogyakarta: Safiria Insania Press, 2004.

Modul Pendidikan dan Pelatihan Prajabatan Golongan III, Etika Publik - Google Search. Jakarta: Lembaga Admiinistrasi Negara Republik Indonesia, 2015.

Nata, Abuddin. Akhlak Tasawuf dan Karakter Mulia. Jakarta: Raja Grafindo, 2012.

Rahayu, Sugi. “Ekspektasi Mahasiswa Terhadap Pelayanan Akademik Fakultas Ilmu Sosial Dan Ekonomi Universitas Negeri Yogyakarta." Jurnal Socia IV, no. 01 (n.d.).

Undang-undang Republik Indonesia, NOMOR 14 TAHUN 2005. TENTANG GURU DAN DOSEN, n.d. 
FITRAH Jurnal Kajian Ilmu-ilmu Keislaman

Vol. 03 No. 2 Desember 2017 